\title{
Observed Changes in Long-Term Climatic Conditions and Inner-Regional Differences in Urban Regions of the Baltic Sea Coast
}

\author{
Michael Richter ${ }^{1 *}$, Sonja Deppisch ${ }^{1}$, Hans Von Storch ${ }^{2}$ \\ ${ }^{1}$ Urban Planning and Regional Development, Hafen City University, Hamburg, Germany \\ ${ }^{2}$ Institute for Coastal Cesearch, Helmholtz-Zentrum, Geesthacht, Germany \\ Email: *michael.richter@hcu-hamburg.de
}

Received November 14, 2012; revised January 1, 2013; accepted January 26, 2013

Copyright (C) 2013 Michael Richter et al. This is an open access article distributed under the Creative Commons Attribution License, which permits unrestricted use, distribution, and reproduction in any medium, provided the original work is properly cited.

\begin{abstract}
This paper presents research outcomes from an investigation into climate change and urban impacts on climate development in urban regions of the Baltic Sea coast. The cities considered were Rostock and Stockholm, and their surrounding regions. The objectives were: 1) to determine whether significant changes in temperature and precipitation have occurred and, if so, to what extent; and 2) to establish whether there is a noticeable urban heat island effect in Stockholm and the medium-sized city of Rostock. Climatic trends were detected by linear regression and the MannKendall test. Different precipitation trends were detected over the whole period of observation. Average annual temperatures increased significantly in both case studies, particularly from the 1970s with highest trends in winter and lowest in autumn (Rostock) and summer (Stockholm). Although changes in temperature extremes were detected for both regions, no overall long-term trend for precipitation extremes was observed. The average temperature in the city of Rostock (Stockholm) was approximately $0.3^{\circ} \mathrm{C}$ to $0.6^{\circ} \mathrm{C}\left(1.2^{\circ} \mathrm{C}\right)$ higher than in the surrounding rural areas had seasonal variations, with maxima in the warm season. The main outcomes were that significant changes in climatic conditions, particularly temperature patterns, have been occurring in the case study regions since the $1980 \mathrm{~s}$, and that there is a considerable urban heat island effect in both Stockholm and Rostock. This could encourage urban planners to consider specific climatic conditions and small-scale climatic influences also in relatively small coastal urban conglomerates in mid latitudes which can follow from land use changes.
\end{abstract}

Keywords: Urban Heat Island; Climate Change; Urban Climate; Baltic Sea; Extreme Events

\section{Introduction}

\subsection{Climate Change in the Baltic Sea Region}

The global climate is changing. The warming trend for the entire globe was $0.04^{\circ} \mathrm{C}$ per decade from 1850 to 2005. Warming has accelerated since the 1980 s to a temperature increase of approximately $0.17^{\circ} \mathrm{C}$ per decade [1]. The warming trend in the Baltic Sea Region, at 0.10/ $0.07^{\circ} \mathrm{C}$ (north/south) per decade, exceeds the global trend. This may be because the globe consists mainly of thermally inert ocean, leading to the more rapid warming of land masses [2]. In this context, the Baltic Sea Region refers to the catchment area of the Baltic Sea, located in north-eastern Europe (see Figure 1). In the period of 1871 to 2004 , the most obvious seasonal trends occurred

"Corresponding author. in spring, with increases of $0.15^{\circ} \mathrm{C}$ and $0.11^{\circ} \mathrm{C}$ per decade in the north and south, respectively. The least warming occurred in summer: $0.06^{\circ} \mathrm{C} / 0.03^{\circ} \mathrm{C}$ per decade [2]. Temperature increases of about $1^{\circ} \mathrm{C}$ in the 20th century have been reported in the drainage basin of the Baltic Sea [2].

Globally, minimum air temperatures rose to a greater extent than maximum air temperatures, meaning that the diurnal temperature range decreased [2]. Reference [3] analysed data concerning the thermal growing season in the Baltic region, and found that it had extended by about one week since 1951. This phenomenon follows a growing east-west gradient between Denmark and Finland, and higher intra-annual variability in the west [3]. Global trends in precipitation behaved differently, depending on latitude. In northern areas above $30^{\circ} \mathrm{N}$, rainfall increased in the 20th century, while it decreased in tropical areas between $10^{\circ} \mathrm{N}$ and $10^{\circ} \mathrm{S}$ [1]. Significant increases in 


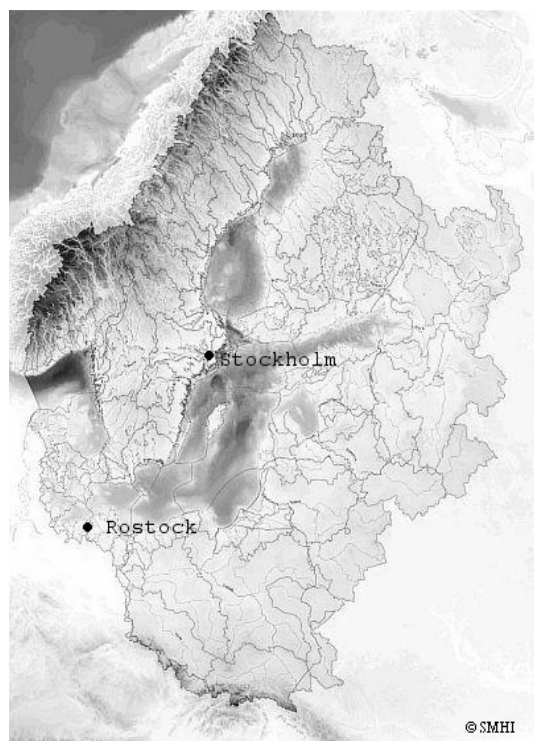

Figure 1. Map of the Baltic Sea region in Northern Europe with its drainage basin outline and the location of the cities of Rostock and Stockholm.

rainfall could be found, for example, in the eastern areas of North and South America, Northern Europe and Central and North Asia. By contrast, the Sahel regions, the Mediterranean, South Asia and southern Africa became drier [1]. According to data by [4], more precipitation was measured in the watershed of the Baltic Sea in the period of 1976 to 2000 than from 1951 to 1975 . In the Baltic region, rainfall increased most visibly in Sweden and on the east coast in the winter and spring seasons [2]. In summer there was increased rainfall in the north, whilst less precipitation fell in the southern part of the region. Overall, virtually no long-term trend is visible since rainfall varies both spatially and temporally [2].

\subsection{Urban Heat Island and Climate Change}

It is a well-known fact that atmospheric conditions in cities differ from those in the surrounding countryside [5]. The urban heat island (UHI) effect describes the phenomenon of differing temperature and other climatic factors between urban areas and their immediate surrounding rural areas. In many cities, this effect is more like a "heat archipel" than an island [6], depending on the urban structure. In addition, there are changes in rainfall, cloud cover, wind conditions and air pollution. These differences are primarily generated in urban areas due to large-scale building structures, sealing and emissions from transport and industry. For a more detailed summary of the reasons for special urban climatic conditions see for example [7]. The average annual air temperature in large cities is $1^{\circ} \mathrm{C}$ to $2^{\circ} \mathrm{C}$ higher than in the immediate surrounding area. In exceptional cases, differences of more than $10^{\circ} \mathrm{C}$ can be determined in mega cities at certain times [8]. Due to the urban climate, inter-annual temperature variability tends to decrease [9]. Stable stratification and low cloud cover promote the formation of an UHI (see [10]); high wind speeds reduce its intensity. Different dependencies of the UHI intensity on wind speed were found by various authors [8,10-12] for example, that the UHI intensity depends on the inverse square root of wind speed $[8,12]$. Reference [8] also discovered a logarithmic relation between the population of a city and the maximum UHI intensity. Following Oke's relation, a medium-sized city such as Rostock, with approximately 200,000 inhabitants, should have a maximum UHI intensity of about $6^{\circ} \mathrm{C}$ to $7^{\circ} \mathrm{C}$. The urban climate effect will impact on an increasing number of people worldwide in the 21 st century because over half of the world's population was city-dwellers in 2010, and this tendency is growing [13]. Regional climate models have revealed that more severe consequences can be expected concerning future climate change in metropolitan areas than in their surrounding areas [14]. It is assumed that the number of summer days $\left(\mathrm{T}_{\max } \geq 25^{\circ} \mathrm{C}\right)$ and hot days $\left(\mathrm{T}_{\max } \geq 30^{\circ} \mathrm{C}\right)$ will increase in many regions [14], and hence the areas where people suffer from thermal stress [15]. Here, heat waves play an important role and are very likely to become more common and severe in Europe [16]. If societies are not prepared for such changes, morbidity and the mortality rate will increase due to the consequences of a higher heat load [15], an example of which occurred in France in the summer of 2003 [17]. In Germany, 3500 people died as a consequence of the 2003 heat wave [18]. Across Europe, there were about 22,000 to 45,000 heatrelated deaths within two weeks of August [19]. These consequences of climate change may, however, be reduced by introducing appropriate adaptation measures to cities. On the other hand, cold stress and mortality is likely to decrease especially in mid-lattitudes [6] and in cities due to the urban climate effects [20].

\subsection{Aim of the Paper}

To evaluate past and current changes in climatic conditions in the case study regions, this paper presents the results of analyses of measured meteorological parameters from different time scales and locations. Annual, seasonal, monthly and daily series were analysed for the case study regions to investigate long-term trends for temperature and precipitation. The effects of UHI were investigated by comparing the measured data of inner-city weather stations with nearby suburban/rural stations with a time resolution of hours and days.

The main research questions were:

How has the climate (temperature, precipitation) changed in the case study regions and are there regional differences in the case study regions, for example, between 
coastal and inland areas?

Is there a noticeable UHI effect in the case study regions, and under which specific weather conditions do the largest temperature differences occur?

\section{Analysis of the Data-Study Cases Rostock and Stockholm}

\subsection{Study Areas}

Rostock, a city on the German Baltic Sea coast (see Figures 1 and 2), is the largest city in the Federal State of Mecklenburg-Vorpommern (Germany). The city is the commercial centre of Mecklenburg-Vorpommern, and had approximately 202,000 inhabitants in 2010 (1990: $250,000)$. One feature of the city is the mouth of the river Warnow, called Breitling. With an area of about $1 \mathrm{~km}^{2}$, the Breitling is located in the middle of the city, with the seaport. The urban centre is located at the southern end of the Warnow delta. The areas with highest degree of sealing are to the west of the Warnow, where most inhabitants live. Rostock is relatively flat; its highest elevation (approximately $50 \mathrm{~m}$ above sea level) is in the southeast. After data from German Meteorological Service (DWD), the average annual temperature is $8.4^{\circ} \mathrm{C}$; the average annual precipitation is $590 \mathrm{~mm}$ (1961-1990, station Rostock-Warnemünde).

The city of Stockholm is the capital of Sweden, located between the Baltic Sea in the west and Lake Malären in the east (see Figures 1 and 2). With an area of $187 \mathrm{~km}^{2}$, the city is slightly larger than Rostock, but its population density is much higher (4.552 per $\mathrm{km}^{2}$ ). Stockholm has about 850,000 inhabitants. After data from Swedish Meteorological and Hydrological Agency (SMHI), the average annual temperature is $6.6^{\circ} \mathrm{C}$ and the average annual precipitation $540 \mathrm{~mm}$ (1961-1990, station Stockholm-Observatorielunden).
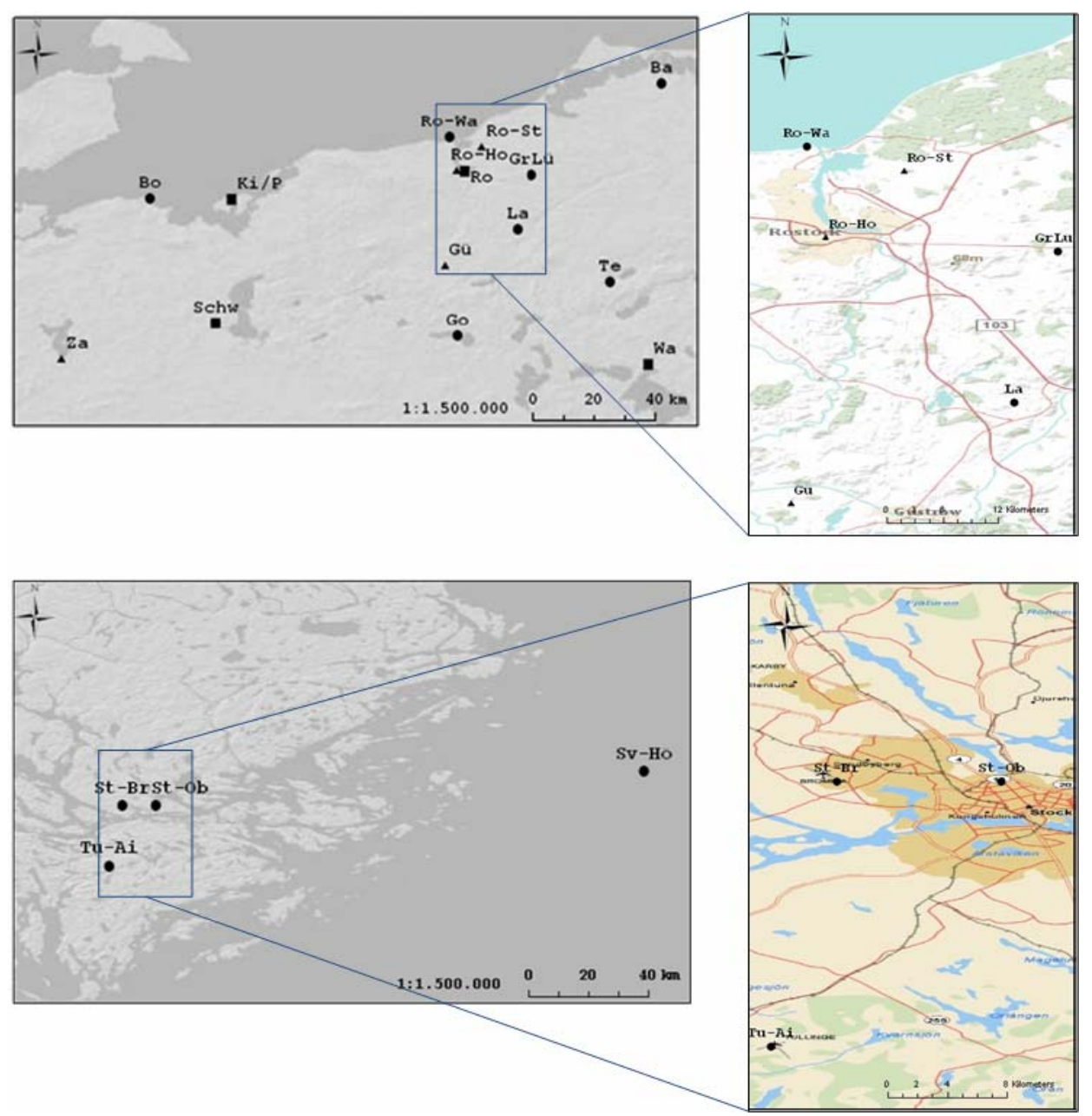

Figure 2. Location of measurement sites for the case study regions Rostock $\left(5^{\circ}{ }^{\circ} 05^{\prime} 20^{\prime \prime} \mathrm{N}, 1^{\circ} 08^{\prime} 24^{\prime \prime} \mathrm{E}\right)$ and Stockholm $\left(5^{\circ} 1^{\prime} 30^{\prime \prime} \mathrm{N}, 1^{\circ} 3^{\prime} 0^{\prime \prime}\right.$ E). Station names: Za-Zarrentin, Bo-Boltenhagen, Schw-Schwerin, Ki/P-Kirchdorf/Poehl, GoGoldberg, Gü-Gülzow, Ro-Wa-Rostock-Warnemünde, Ro-Ho-Rostock-Holbeinplatz, Ro-Rostock, Ro-St-RostockStuthof, GrLü-Groß Lüsewitz, La-Laage, Ba-Barth, Te-Teterow, Wa-Waren, Tu-Ai-Tullinge Airport, St-BrStockholm-Bromma, St-Ob—Stockholm-Observatorielunden, Sv-Ho—Svenska-Högarna. 


\subsection{Measurement Sites, Data Collection and Preparation}

Homogenised monthly data of temperature and precipitation from DWD were used to analyse the long-term climatic trends in the region of Rostock. All of the chosen stations were located in Mecklenburg-Vorpommern, within $100 \mathrm{~km}$ of Rostock (see Figure 2). Trends for extreme values were examined using daily data concerning precipitation and maximum and minimum temperatures from various stations. This data was also supplied by DWD. In addition, data from the air monitoring network of Mecklenburg-Vorpommern was supplied by the State Office for Environment, Nature Conservation and Geology to examine the urban effects on temperature, in particular. The stations were close to the city centre (RostockHolbeinplatz) located near a busy road, or at rural sites near Rostock (Rostock-Stuthof, Gülzow) surrounded by agricultural areas or grassland. The station Rostock-Warnemünde is located directly behind the dunes of the Baltic Sea Coast. The UHI intensity was calculated from the difference between the temperatures recorded at the weather station near the city centre (Rostock-Holbeinplatz) and those at the rural stations (Rostock-Stuthof, RostockWarnemünde, Gülzow). Data for the Stockholm region (see Figure 2) was provided by the Swedish Meteorological and Hydrological Agency (SMHI). This data comprised the long-term daily series of Stockholm-Observatorielunden 1756-2009 [21,22], from which effects such as the UHI effect (see [23]) were removed. Temperature extremes were calculated using the 3-hour average data from Stockholm-Bromma and Svenska-Högarna (19612009) and by calculating the daily maximum and minimum temperature. Urban effects on temperature were computed using the weather station at Stockholm-Bromma airport as the urban station and Tullinge Airport as the rural station. Stockholm-Bromma was used as urban station instead of Stockholm-Observatorielunden because of free availability of data from 3-hourly measurements. The time series for evaluating climatic changes were divided into different normal periods of 30 years' length. Due to the expected different results for both climatic changes and the UHI effect at several times of the year, the time series were divided further into seasons by months (DJF/ $\mathrm{MAM} / \mathrm{JJA} / \mathrm{SON}$ ).

\subsection{Statistical Methods}

To check the data supplied by the air monitoring network of Mecklenburg-Vorpommern, outliers were identified and removed by checking the data series graphically and looking for implausible differences between measured temperature values. This data was statistically reviewed and compared with data from DWD by calculating descriptive statistics, correlation coefficients and cross- correlations on a daily and hourly basis between the time series. Various statistical methods were applied to determine and test the significance of long-term trends. Trends concerning annual or seasonal temperature and precipitation were calculated using linear regression with leastsquare fitting to obtain a linear trend per time interval. The significance of these trends was tested using the MannKendall test [24]. Due to the possible serial correlation of the time series, the Mann-Kendall test may become liberal, falsely rejecting the null hypothesis [25]. For this reason, all time series were filtered by a "prewhitening" approach [25] to eliminate the problems caused by serial correlation. These statistical analyses were conducted using the ANCLIM software by Petr Štěpánek [26] and SPSS Statistics. Gliding linear trends of annual mean temperatures were estimated by linear regression using moving 31 -year windows. The trends in extremes were calculated using the RClimDex Package for R. After a simple quality control of the data (replacement of missing \& unreasonable values, identification of outliers), the programme computes all 27 core indices recommended by the $\mathrm{CCl} /$ CLIVAR Expert Team for Climate Change Detection Monitoring and Indices (ETCCDMI), as well as other temperature and precipitation indices with user-defined thresholds [27].

\section{Results}

This section is divided into two main parts. In the first part, a description is given of the long-term climatic changes in temperature, precipitation and indices of extremes in the case study regions. In the second part, the urban impacts on temperature and the dependence of the UHI on wind speed and cloud cover are explored.

\subsection{Long-Term Changes}

Temperature changes in the Rostock region were examined with monthly data from the stations at Schwerin, Rostock-Warnemünde (Figure 3) and Teterow. Representative for the Rostock region, Figures 3-5 show results from the Rostock-Warnemünde station. For the whole periods under study, there are positive trends focusing on an annual base of about $0.25^{\circ} \mathrm{C} /$ decade (Figure 4(a)) (significant $(\mathrm{p}<0.05)$ for Rostock-Warnemünde, Schwerin). The largest increases in average annual temperature occurred in the period from 1976 to 2005, with linear trends of $0.5^{\circ} \mathrm{C}$ to $0.62^{\circ} \mathrm{C} /$ decade. When focusing on seasonal trends, it becomes apparent that autumn (SON) warmed least considerably at all stations. The strongest increases in seasonal temperature occurred in winter between 1976 and 2005, at Warnemünde with a trend of $0.79^{\circ} \mathrm{C} /$ decade (Figure 4(a)). Temperatures in spring (MAM) and summer (JJA) increased by nearly $0.7^{\circ} \mathrm{C} /$ decade at Warnemünde. There seems to be a stronger 


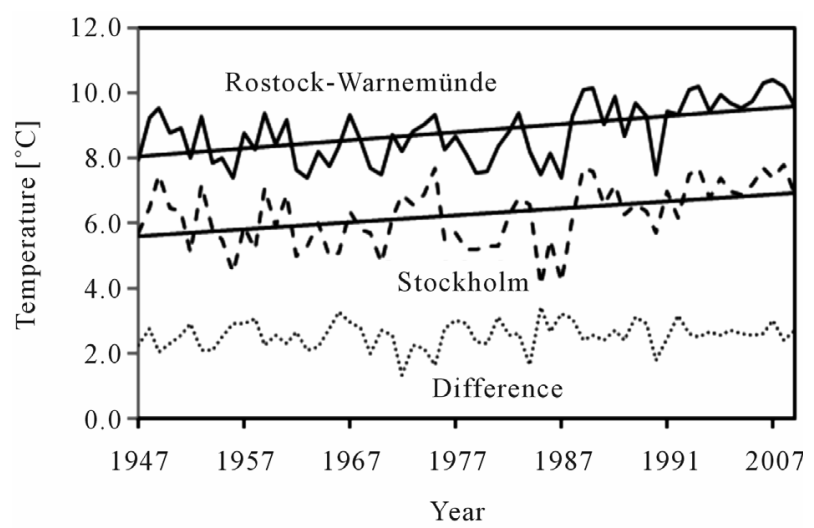

Figure 3. Annual average temperature (1947-2009) at Rostock-Warnemünde with linear trend from 1951 to 2005 and Stockholm-Observatorielunden with linear trend from 1947 to 2009 and plotted differences between these annual temperatures.

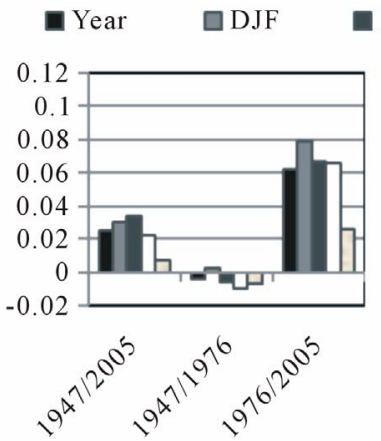

(a)
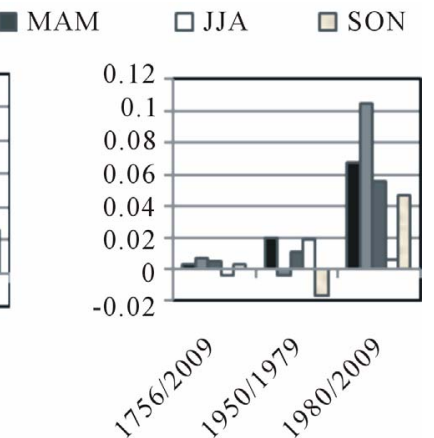

(b)
Figure 4. Linear trends $\left[{ }^{\circ} \mathrm{C}\right.$ per year] of observed annual temperatures at Rostock-Warnemünde weather station (a) and Stockholm-Observatorielunden (b). Trends are for different seasons or for the whole year and, due to different measurement periods and data availability, for different periods.

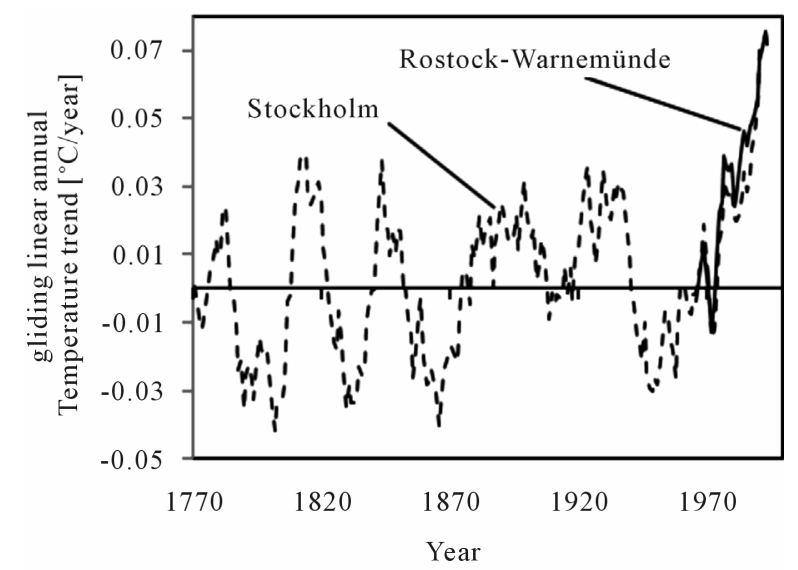

Figure 5. Gliding linear trends of the annual mean temperature, estimated by 31-year windows, of weather stations Rostock-Warnemünde and Stockholm-Observatorielunden for the time between 1951 and 2009. increase in annual average temperatures since the late 1980s for all series (see Figure 3, for instance). For Stockholm, the long-term series from 1756 to 2009 [21, 22] was used to examine trends in average annual temperatures. These results (Figures 3 and $\mathbf{4 ( b )}$ ) also indicate an increase in average annual temperature in the late 1980s. During the period from 1756 to 2009, slight increases $\left(0.03^{\circ} \mathrm{C}\right.$ to $0.07^{\circ} \mathrm{C} /$ decade $)$ occurred throughout the year and for all seasons with the exception of summer, where a decrease of $0.04^{\circ} \mathrm{C} /$ decade was found. All trends were significant $(\mathrm{p}<0.05)$ for this period. No significant trends were detected for the period from the $1950 \mathrm{~s}$ (1950-1979). These differences ranged from $-0.17^{\circ} \mathrm{C} /$ decade in autumn to $0.2^{\circ} \mathrm{C} /$ decade for the entire year. For the period after 1980 , trends range from $0.06^{\circ} \mathrm{C} /$ decade in summer to $1.05^{\circ} \mathrm{C} /$ decade in winter (Figure 4(b)). For the entire year, the trend is significant with $0.67^{\circ} \mathrm{C} /$ decade $(\mathrm{p}$ $<0.05)$. Gliding linear annual mean temperature trends, estimated by linear fit in moving 31-year windows (Figure 5), showed temporal variations in the rate of change. The longer time series for Stockholm showed variations ranging from -0.4 to $+0.4^{\circ} \mathrm{C} /$ decade until the $1980 \mathrm{~s}$. From this point in time (1985 for Rostock and 1989 for Stockholm), the trend values exceeded this range. After 1972/1973, the rate was positive and accelerated over the entire period, with a few interruptions. The maximum linear 31-year trend was achieved in both Rostock and Stockholm, at $0.75^{\circ} \mathrm{C} /$ decade, in 1993 (period 19782003). Gliding linear trends were similar over the entire period from 1951 to 2009. After 1972, the warming trend at Rostock-Warnemünde was almost always higher.

The time series of precipitation were filtered by a "prewhitening" approach [25] to eliminate the problems caused by serial correlation and linear trends were calculated with 10-year running means and corresponding significance was detected with the Mann-Kendall-Test.

For any period, there was an overall positive trend for all seasons and for the whole year for all stations, as was the case for temperature. The linear 31-year gliding mean precipitation trend at Rostock weather station (Ro in Figure 2) was negative until 1975 (Figure 6), after which the trend was positive up to 2009 . There was a maximum increase in $1986(1971-2001)$ at $6.9 \mathrm{~mm} / \mathrm{a}$, and decreasing but positive trends thereafter.

Table 1 shows linear trends of observed 10-year running means of annual and seasonal precipitation from 1951 to 2005 . No significant trends were detected by the Mann-Kendall Test for the period from 1951 to 2005 (p $\leq 0.05$ ). For Schwerin, Rostock and Kirchdorf, precipitation increased by $0.32 \mathrm{~mm} / \mathrm{a}$ to $0.49 \mathrm{~mm} / \mathrm{a}$. The largest increases in precipitation occurred in winter and autumn; by contrast, decreases or small increases were mainly recorded in spring and summer. The annual linear precipitation trend for Waren was negative for the whole 


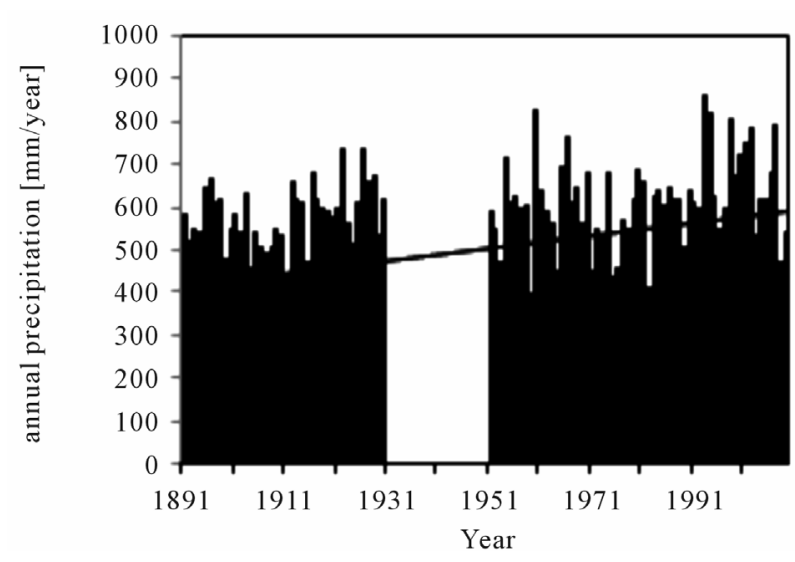

(a)

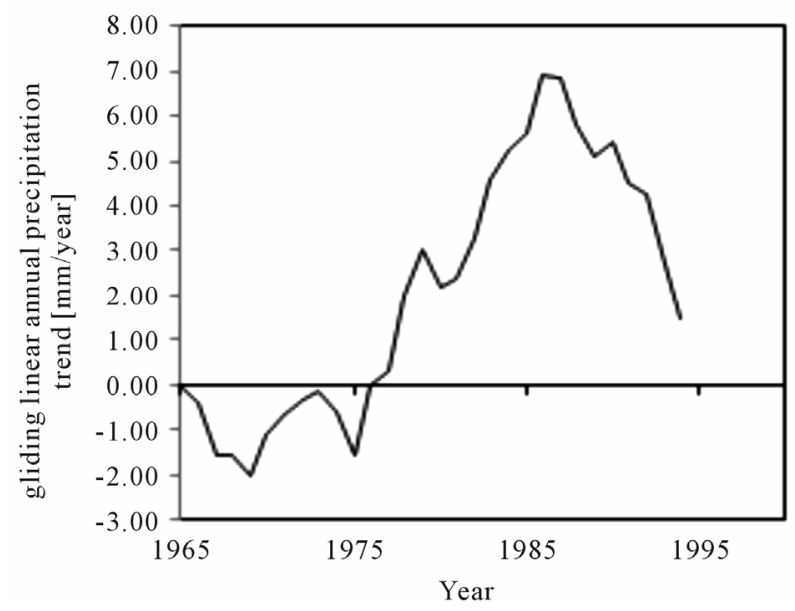

(b)

Figure 6. Annual precipitation at Rostock weather station with linear trend (a) and 31-year gliding linear trend (b) for 1951 to 2005.

Table 1. Linear trends [mm per year] of observed 10-year running means of annual precipitation from 1951 to 2005. Trends are for different seasons and for the whole year.

\begin{tabular}{cccccc}
\hline Station & Year & DJF & MAM & JJA & SON \\
\hline Schwerin & 0.48 & 0.52 & 0.135 & -0.67 & 0.57 \\
Rostock & 0.49 & 0.41 & 0.07 & -0.09 & 0.63 \\
Kirchdorf & 0.32 & 0.15 & -0.003 & 0.29 & 0.32 \\
Waren & -1.5 & -0.16 & -0.39 & -0.86 & -0.51 \\
\hline
\end{tabular}

year and for all seasons.

Climate indices for the weather stations were calculated from daily values of maximum temperature, minimum temperature and precipitation. Table 2 shows values with significant $(\mathrm{p}<0.05)$ increasing or decreasing trends. It can be seen that the length of the thermal growing season (GSL) increased significantly for all stations. The number of frost days per year (FD0) decreased, and the number of summer days (SU25) increased sig- nificantly at most locations.

Other indices show only a few significant decreases or increases at various sites. Schwerin is the only station with an increase in extreme precipitation indices, R20 $\mathrm{mm}$ (number of very heavy precipitation days, annual count of days when $\mathrm{p}>20 \mathrm{~mm}$ ) and R95 pp (very wet days, annual total precipitation when $\mathrm{p}>95$ th percentile).

Indices for the Stockholm region were computed using data from Stockholm-Bromma and Svenska-Högarna (Table 3).

Here, the number of ice days per year (ID0) and the number of frost days per year (FD0) decreased significantly, and the monthly minimum value of daily minimum temperature (TNn) and the monthly maximum value of daily minimum temperature (TNx) increased significantly at both sites from 1961 to 2009. Cold extremes (FD0, ID0) decreased by about 0.5 to 1 day per year. Additionally, the number of summer days (SU25), the length of the growing season (GSL) and the monthly maximum and minimum value of daily maximum temperature (TXx, TXn) increased at Svenska Högarna.

\subsection{Urban Impacts}

For the Rostock region, data with a time step of one hour were available for Rostock-Warnemünde (HRO_Warnemuende), Rostock-Holbeinplatz (HRO_Holbeinplatz), Rostock-Stuthof (HRO_Stuthof) and Guelzow (see Figure 2). Table 4 shows descriptive statistics of the hourly temperature measurements. The station near the city centre of Rostock (HRO Holbeinplatz) had the highest mean temperature $\left(10.2^{\circ} \mathrm{C}\right)$ during the period from 2001 to 2009.

Rostock-Holbeinplatz and Rostock-Warnemünde had considerably higher absolute minimum temperatures $\left(-13.3^{\circ} \mathrm{C}\right.$ and $\left.-13.9^{\circ} \mathrm{C}\right)$. The mean temperature difference between the station in the inner city (HRO-Holbeinplatz) and rural stations near the city, or the mean UHI effect, is between $0.3^{\circ} \mathrm{C}$ and $0.6^{\circ} \mathrm{C}$. The same values are produced when focusing on daily average temperatures (Table 5). Here, the mean temperature difference between HROHolbeinplatz and Gross Lüsewitz weather station $\left(\mathrm{Gr}_{-}\right.$ Luesewitz, rural station, distance about $15 \mathrm{~km}$ ) was even $1.4^{\circ} \mathrm{C}$. The average diurnal cycle (Figure 7) shows that at night, HRO Warnemünde had the highest temperatures, which were about $1^{\circ} \mathrm{C}$ higher than at HRO_Stuthof and Guelzow at 5:00 hrs. HRO_Holbeinplatz was warmer than these stations, but about $0.5^{\circ} \mathrm{C}$ colder than at $\mathrm{HRO}_{-}$ Warnemuende at night. At 9:00 hrs the mean temperatures were the same; temperatures at HRO_Holbeinplatz increased more rapidly than at the other locations until 14:00/15:00 hrs, when the average differences between the nearest stations-CHRO_Stuthof and HRO_Warnemünde-were about $1{ }^{\circ} \mathrm{C}$ to $2^{\circ} \mathrm{C}$. From late afternoon onwards, temperatures decreased until they again reached 
Table 2. Significant $(\mathrm{p} \leq \mathbf{0 . 0 5})$ changes in climatic core indces (following [27]) in days/year or ${ }^{\circ} \mathrm{C} / \mathrm{year}$ for various sites in and around Rostock.

\begin{tabular}{|c|c|c|c|c|c|c|c|}
\hline Climate indices & Warne-Münde & Teterow & Schwe-Rin & Gross Lüse-Witz & Goldberg & Boltenhagen & Barth \\
\hline DTR & & 0.018 & & & & -0.009 & 0.013 \\
\hline FD0 & -0.385 & & -0.146 & -0.568 & -0.432 & -0.49 & \\
\hline ID0 & & -0.241 & & & & -0.2 & \\
\hline GSL & 0.91 & 0.668 & 0.335 & 0.901 & 0.901 & 0.758 & 0.79 \\
\hline $\mathrm{R} 20 \mathrm{~mm}$ & & & 0.009 & & & & \\
\hline $\mathrm{R} 95 \mathrm{pp}$ & & & 0.35 & & & & \\
\hline SU25 & 0.169 & 0.329 & & 0.268 & 0.209 & & 0.16 \\
\hline $\mathrm{TNn}$ & 0.05 & & & & 0.083 & 0.064 & \\
\hline $\mathrm{TNx}$ & 0.028 & & 0.011 & & 0.002 & 0.022 & \\
\hline TXx & & 0.058 & & 0.051 & & & \\
\hline TR20 & 0.015 & & & & & & \\
\hline
\end{tabular}

Table 3. Significant $(p \leq 0.05)$ changes in climatic core indices (following [27]) in days/year or ${ }^{\circ} \mathrm{C} /$ year for various sites in and around Stockholm.

\begin{tabular}{ccc}
\hline Climate indices & Stockholm-Bromma & Svenska Högarna \\
\hline SU25 & -0.485 & 0.056 \\
ID0 & -0.531 & -0.667 \\
FD0 & -0.985 \\
GSL & & 0.499 \\
TXx & & 0.078 \\
TXn & & 0.084 \\
TNx & 0.028 & 0.048 \\
TNn & 0.092 & 0.096 \\
\hline
\end{tabular}

Table 4. Descriptive statistics for stations including temperature range, absolute minimum and maximum temperature, mean temperature and standard deviation for hourly data measured 2001-2009 in ${ }^{\circ} \mathrm{C}$.

\begin{tabular}{cccccc}
\hline Station & Range & Min & Max & Mean & Std dev \\
\hline HRO_Holbeinplatz & 49.3 & -13.9 & 35.4 & 10.2 & 7.6 \\
$\begin{array}{c}\text { HRO_Stuthof } \\
\text { Guelzow }\end{array}$ & 54.2 & -19.2 & 35.0 & 9.6 & 7.4 \\
HRO_Warnemuende & 46.4 & -18.4 & 36.0 & 9.9 & 7.7 \\
\hline
\end{tabular}

Table 5. Descriptive statistics for stations including temperature range, absolute minimum and maximum temperature, mean temperature and standard deviation for daily data measured 2001-2009 in ${ }^{\circ} \mathrm{C}$.

\begin{tabular}{cccccc}
\hline Station & Range & Min & Max & Mean & Std dev \\
\hline HRO_Holbeinplatz & 38.8 & -11.0 & 27.8 & 10.2 & 7.1 \\
HRO_Stuthof & 37.7 & -11.4 & 26.3 & 9.6 & 6.8 \\
HRO_Warnemünde & 36.2 & -10.7 & 25.5 & 9.9 & 6.8 \\
Laage & 38.7 & -12.2 & 26.5 & 9.3 & 7.1 \\
Gr_Luesewitz & 37.8 & -12.4 & 25.4 & 8.8 & 6.9 \\
Guelzow & 38.7 & -11.6 & 27.1 & 9.9 & 7.1 \\
\hline
\end{tabular}

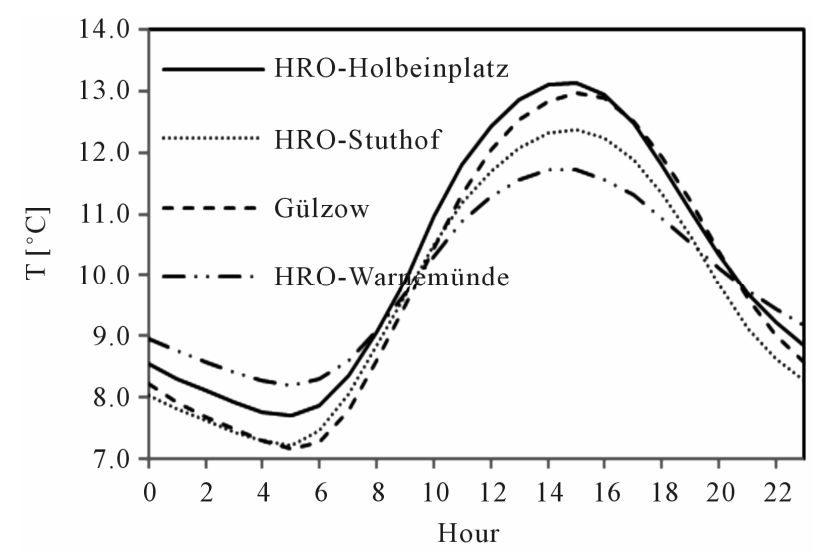

Figure 7. Average diurnal temperature cycles for different stations 2001-2009. 
a point when they were nearly the same, at 20:00/21:00 hrs.

This pattern remained the same throughout the year. However, temperature differences between HRO_Holbeinplatz and HRO_Warnemünde were lower at night $\left(<0.6^{\circ} \mathrm{C}\right)$ and higher in the early afternoon (up to $2.5^{\circ} \mathrm{C}$ ), particularly in spring (MAM) and summer (JJA, Figure 8(b)). The differences in temperature over the day in winter (DJF, Figure 8(a)) and autumn (SON) were less considerable. When comparing the temperature differences at HRO_Holbeinplatz and HRO_Stuthof, the highest temperature difference was always in the early afternoon. In summer there was another UHI maximum at midnight and two minima at 7:00 hrs and 19:00 hrs. Minima of temperature differences between HRO_Holbeinplatz and Guelzow occurred in the late afternoon in summer and winter; the summer maximum was in the early morning (5:00/6:00 hrs) and the winter maximum was at midday. Figure 9 shows that the monthly mean UHI was highest in May, with a difference of over $1{ }^{\circ} \mathrm{C}$ for

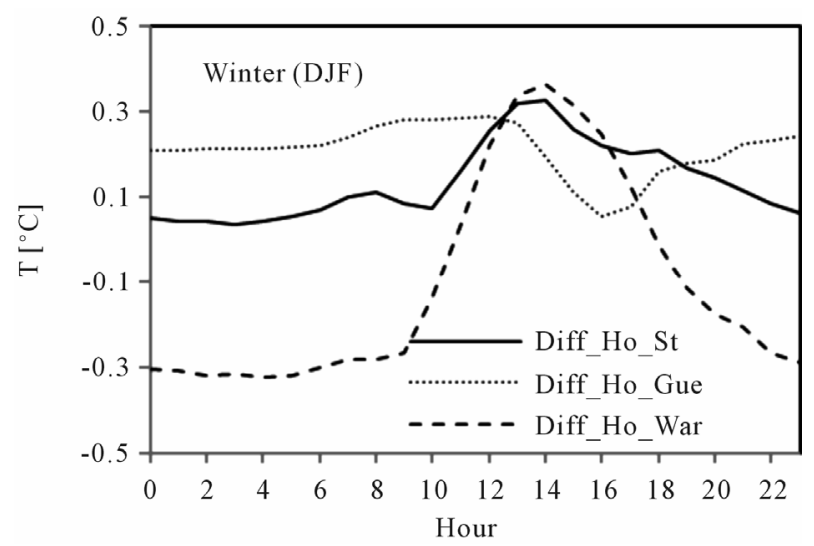

(a)

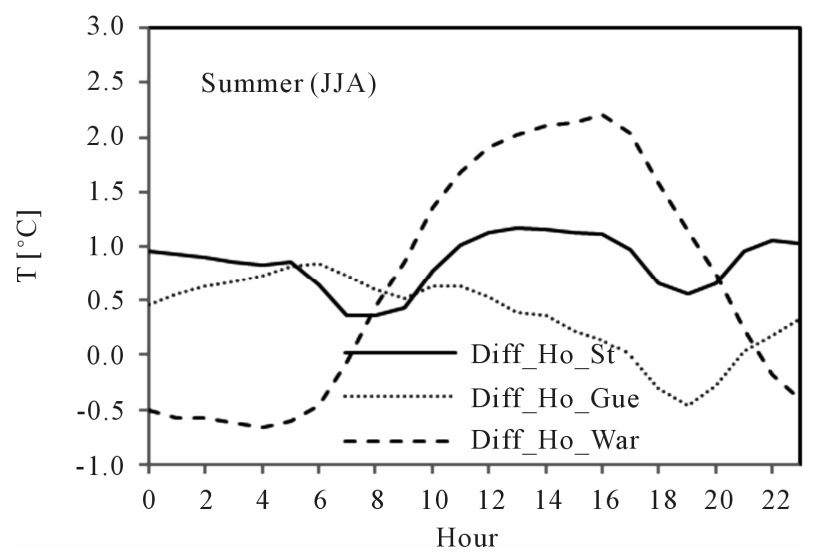

(b)

Figure 8. Average diurnal cycle of UHI intensity for winter months ((a), DJF) and summer months ((b), JJA) for 20012009. UHI intensities were computed from each difference between Rostock-Holbeinplatz (Ho) and Rostock-Stuthof, Rostock-Warnemünde and Gülzow weather stations.

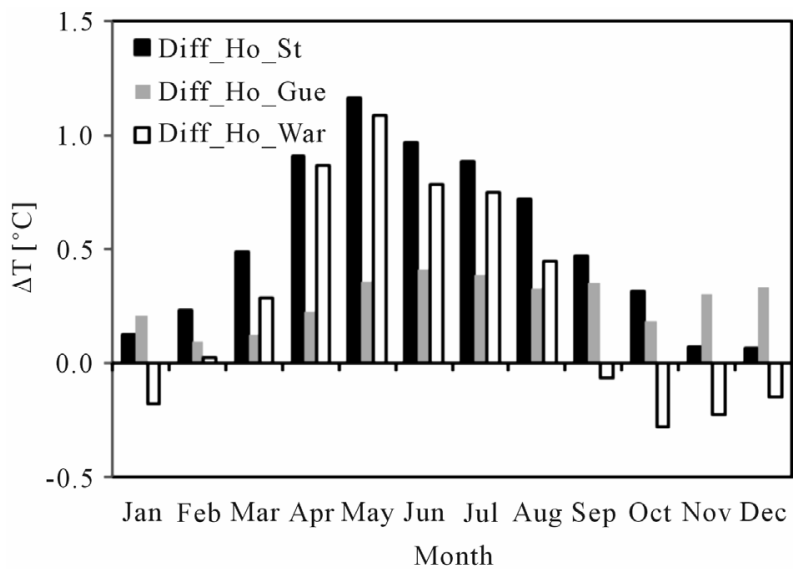

Figure 9. Average monthly UHI intensity for 2001 to 2009. UHI intensities were computed from each difference of monthly averages between Rostock-Holbeinplatz (Ho) and Rostock-Stuthof, Rostock-Warnemünde and Gülzow weather stations.

HRO_Warnemünde and HRO_Stuthof, and lowest in winter. When HRO_Holbeinplatz was compared with the coastal station HRO Warnemünde, average temperatures near the coast were higher in autumn and winter. There is no such clear seasonal cycle for the difference between HRO_Holbeinplatz and Gülzow but two maxima in summer and early winter and two minima in autumn and at the end of winter. The maximum UHI intensity over the observed period was $8.5^{\circ} \mathrm{C}$ for HRO_Stuthof and $8.3^{\circ} \mathrm{C}$ for Guelzow for hourly measurements and $4.4^{\circ} \mathrm{C}$ and $5.7^{\circ} \mathrm{C}$, respectively, for daily mean temperatures. Data from two stations was compared for the Stockholm region. Stockholm-Bromma is a weather station at StockholmBromma Airport to the northwest of the city centre; Tullinge Airport is a more rural station south of Stockholm. Three-hourly temperature data was available for the period from 1996 to 2009 for both sites, which were then compared. In this period, Stockholm-Bromma had an average temperature of $7.4^{\circ} \mathrm{C}$ and Tullinge Airport $6.2^{\circ} \mathrm{C}$. This would be a mean UHI of $1.2^{\circ} \mathrm{C}$, comparable, for example, to Hamburg [12] and London [28]. The maximum UHI intensity for 3-hourly measurements and daily means (in brackets) is $12.9^{\circ} \mathrm{C}\left(8.3^{\circ} \mathrm{C}\right)$, the maximum Urban cool island (UCI) intensity is $-5.4^{\circ} \mathrm{C}\left(-2.4^{\circ} \mathrm{C}\right)$, respectively. As in Rostock, the diurnal cycle of the UHI changed throughout the year. As can be seen in Figure 10, the winter UHI was only weak, averaging at between $0.4^{\circ} \mathrm{C}$ at midday and $0.8^{\circ} \mathrm{C}$ before midnight. There were significant diurnal variations of the UHI intensity during the other seasons. The average UHI was at its maximum at around midnight, and was highest in summer, at about $2.3^{\circ} \mathrm{C}$. The average UHI intensities decreased from 3:00 hrs to 6:00 hrs; the minimum level was at around 9:00 hrs, after which UHI intensities increased again until around midnight. 


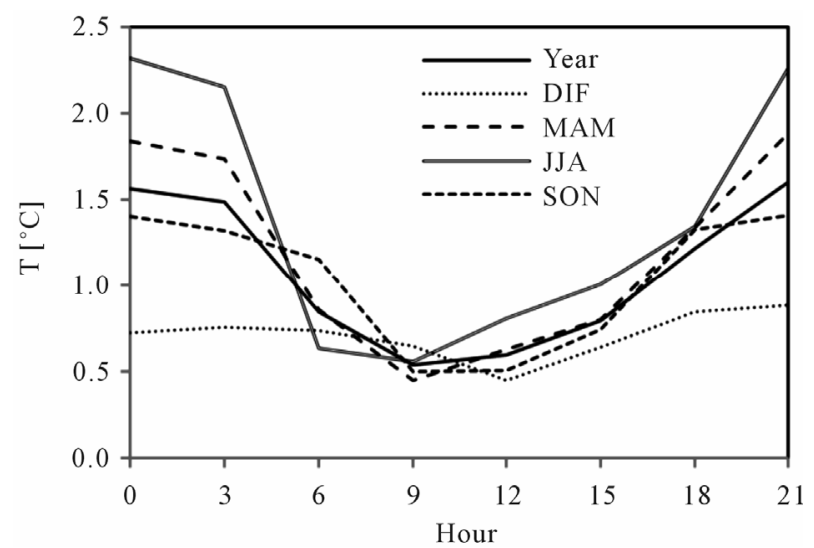

Figure 10. Average diurnal cycle of UHI intensity for the whole year, winter months (DJF), spring months (MAM), summer months (JJA) and autumn months (SON) for 1996 to 2009. UHI intensities were computed from the difference between averages at Stockholm-Bromma and Tullinge-Airport.

The dependence of the UHI intensity on different meteorological conditions has been reported in various studies $[10,12,29]$. Here it was examined whether there was a significant relationship between the daily mean UHI intensity (daily mean $\Delta \mathrm{T}$ between Rostock-Holbeinplatz and Rostock-Stuthof) in Rostock and the conditions of wind speed and cloud cover. Rostock-Warnemünde weather (synoptic station) station was used as the reference station for the meteorological conditions due to the reliability of its data. Because of the eventual disruptive influences of f.e. land-sea breeze circulation on wind speed measurement, the analysis was performed with daily wind speed data of other synoptic stations near Rostock (Schwerin, Goldberg), too. A linear regression analysis with the least square method was carried out for all data and seasons with Equation (1):

$$
U H I=a * x+b
$$

where $x$ is the daily mean of wind speed or cloud cover. For wind speed, the parameters are given in Table 6. All regressions are significant $(\mathrm{p}<0.05)$. Parameters for the other stations were very similar in order of magnitude and seasonality and are not shown here. The coefficient of determination $r^{2}$ ranged from 0.11 in winter to 0.20 in autumn. The value $b$ determines the theoretical daily average UHI intensity when the average daily wind speed is 0 . This ranges from $0.42^{\circ} \mathrm{C}$ in winter to $1.53^{\circ} \mathrm{C}$ in spring. The stronger determined variance of UHI intensity can be explained by cloud cover (Table 7, all significant for $p<0.05)$. The $r^{2}$ values are mostly higher than those for wind speed except for winter and autumn. For cloud cover, the strongest dependence of UHI intensity is during spring and summer; the least dependence is in winter. The theoretical UHI intensity when there was no cloud cover is $0.3^{\circ} \mathrm{C}$ in winter and $1.81^{\circ} \mathrm{C}$ in summer.
Table 6. Parameters of linear regression between daily average UHI intensity (temperature difference between Rostock-Holbeinplatz and Rostock-Stuthof) and wind speed at Rostock-Warnemünde.

\begin{tabular}{cccc}
\hline & $\mathrm{a}$ & $\mathrm{b}$ & $\mathrm{r}^{2}$ \\
\hline Year & -0.11 & 1.08 & 0.16 \\
DJF & -0.05 & 0.42 & 0.11 \\
MAM & -0.15 & 1.53 & 0.19 \\
JJA & -0.12 & 1.40 & 0.16 \\
SON & -0.01 & 0.74 & 0.20 \\
\hline
\end{tabular}

Table 7. Parameters of linear regression between daily average UHI intensity (temperature difference between Rostock-Holbeinplatz and Rostock-Stuthof) and cloud cover (in \%) at Rostock-Warnemünde.

\begin{tabular}{cccc}
\hline & $\mathrm{a}$ & $\mathrm{b}$ & $\mathrm{r}^{2}$ \\
\hline Year & -0.02 & 1.36 & 0.22 \\
DJF & 0.00 & 0.30 & 0.02 \\
MAM & -0.02 & 1.63 & 0.25 \\
JJA & -0.02 & 1.81 & 0.27 \\
SON & -0.01 & 0.83 & 0.14 \\
\hline
\end{tabular}

\section{Discussion}

Trend analyses for long-term precipitation and temperature on an annual and seasonal basis revealed significant changes in climatic conditions in both case study regions, Rostock and Stockholm. All of the examined time series of temperature measurements showed sustained accelerated warming since the 1980s compared to earlier periods. This is in line with increased warming on a global scale [30] and in the Baltic Sea catchment [2] since the 1980s. Both study areas warmed most in winter months (Rostock: $0.7^{\circ} \mathrm{C}$ to $0.79^{\circ} \mathrm{C} /$ decade, Stockholm: $1.05^{\circ} \mathrm{C} /$ decade). This is in line with the BACC-Report [2], which stated that the warming trends are higher in northern latitudes. Differences exist in the least warming periods. The Rostock region warmed least in autumn $\left(-0.1^{\circ} \mathrm{C}\right.$ to $0.26^{\circ} \mathrm{C} /$ decade); for the Stockholm region, the lowest warming trend $\left(0.06^{\circ} \mathrm{C} /\right.$ decade $)$ was in summer. Our analysis of the precipitation time series revealed no clear increasing or decreasing trend in the Rostock region, but a strong variability in annual precipitation quantities. The long-term trends were partly significant, but only in the order of magnitude of $1 \%$ of annual precipitation quantities. The shorter 31-year gliding linear trend at Rostock weather station was up to the order of magnitude of $1 \%$ of the annual precipitation quantity. Three of the four stations have negative trends in summer; as expected, the two most continental stations, Schwerin and Waren, had the 
greatest negative trend. GSL (growing season length) changed significantly for most stations in the Rostock region at nearly one day per year for the whole measured period (in most cases from 1947 to 2009). This trend can be assumed to be stronger when focusing on the last 30 years only, which is the case for all of the calculated indices. The number of ice days and frost days per year decreased for all stations in both regions, albeit not always significantly. In the northernmost region, Stockholm, the decrease is up to one day higher per year. The number of summer days per year increased in all cases (most of them significantly), at 0.056 to 0.329 days per year, by a smaller amount than for cold extremes. The number of tropical nights only increased significantly at Rostock-Warnemünde. This may be due to the generally rare occurrence of these events at other stations. Extremes such as summer days and tropical nights can become more important when considering UHI intensities, which are added to the high temperatures in the regions and are not considered in these climatic trends. Both case studies showed considerable UHI intensities, especially in the warm period (spring and summer). The UHI intensity was at its minimum in winter. The maximum UHI intensities slightly exceeded the expectations concluded from Oke's relationship between maximum UHI intensity and number of inhabitants. [7] generalised UHI intensities by reviewing empirical studies. He found that they were greatest in summer, during anticyclonic conditions, at night, and that they increased with decreasing wind speed, cloud cover and increasing city size or population. There were differences in time of occurrence of the maximum UHI intensity between the case studies. The maximum temperature difference at Stockholm occurred in the middle of the night and the minimum at midday. In Rostock, however, two maxima occurred: the larger in the early afternoon and the smaller at night. With its location near the Baltic Sea Coast, a land-sea breeze circulation could be expected which could suppress the UHI in the afternoon. In this special case of Rostock and the location of the measurement station Rostock-Holbeinplatz this seemed not to be the case. Similar to Rostock, maximum heat island intensities approaching $8^{\circ} \mathrm{C}$ on sunny midsummer days were reported for Saskatoon, Canada, a similar sized city with 200,000 inhabitants [31] and, for example, Helsinki [32] and Lodz [33]. The mean UHI of $1.2^{\circ} \mathrm{C}$ at Stockholm is comparable, for example, to Hamburg [12] and London [28], cities with many more inhabitants than Stockholm. This confirms the hypothesis that UHI intensities tend to increase from low to high latitudes [34]. The warmer temperatures at Rostock-Warnemünde compared to Rostock-Stuthof could be due to the influence of the Baltic Sea temperature, since this station is located directly at the coast. This hypothesis is supported by the diurnal temperature cycle of Rostock-Warnemünde, which has a significantly lower temperature range. The expectations of the relationship between UHI intensity and large-scale meteorological conditions were confirmed for the Rostock region. There was a negative dependence of UHI intensity on both wind speed and cloud cover. This has already been shown by various studies $[8,12,35]$. With $\mathrm{r}^{2}=0.22$, the determined variance for cloud cover for the whole year was similar to Hamburg [35]. The $r^{2}$ values have contrasting characteristics through the seasons. Whereas the dependence of UHI intensity on cloud cover is highest in summer and spring, for wind speed it is highest in spring and autumn. This is important when considering the expected climatic changes accompanied by an increase in summer highpressure situations with low wind speed and cloud cover [36]. This could possibly lead to the accumulation of situations with high UHI intensities and to diverse impacts induced by these intensities, such as thermal stress to humans and to urban ecosystems, and increased air pollution. Finally, this study could only show results for special locations and limited time periods due to its concentration on a few weather stations at sites in the two chosen cities and the set observation times. Further weather stations at different locations with different degrees of sealing, plant cover, canopy forms, building structures, etc. would be required to generate a better understanding of the UHI and its accompanying effects. For example, Rostock-Holbeinplatz weather station is not located at the heart of the city, which has even more sealed areas and buildings, and less vegetation cover. Hence, the maximum UHI intensity in the inner city of Rostock could be even higher. With longer time series of meteorological parameters in cities, it would even be possible to evaluate ongoing effects of climate change on the urban climate, such as whether cities are affected to a greater extent by temperature changes than their surrounding countryside.

\section{Conclusion}

This research confirms the findings of various other studies which determined that climate changes (for this study, temperature and precipitation) in the case study regions and the speed of change have increased since the 1980s. No uniform trend was detected for precipitation, although the annual amount of precipitation increased in most cases, and there is less precipitation in summer and more in winter. The changes in climatic conditions were proved for the case study regions of the Baltic Sea coast, Rostock and Stockholm. The changes in temperature are most noticeable in winter, and particularly affect the cold extremes, expressed in decreasing ice and frost days. In the northernmost region, Stockholm, warming in winter months is significantly higher; for Rostock, this is the case in summer. Given that the observed temperature trends (since the 1980s) will continue, average annual tempera- 
tures could rise by up to $1^{\circ} \mathrm{C}$ in 20 years. This increase in temperature could be problematic for urban regions, which already have average temperatures and maximum UHI intensities that are several degrees Celsius higher (e.g. Rostock $8.5^{\circ} \mathrm{C}$ ) at night and over the day. In the investigated temperate climatic regions with expected land-sea breeze circulations, however, it does not yet seem to constitute a serious problem. Nevertheless, there are benefits for cities due to the UHI like less energy consumption for heating and less cold stress for people. Both case studies had significant UHI effects with maximum intensities in summer and at night in Stockholm and in the afternoon in Rostock. For Rostock it was proved that the UHI intensity increases with decreasing wind speed and cloud cover, whereas cloud cover seemed to have a greater influence. With a possible increase in heat wave occurrence and intensity due to climate change, urban regions must make precautions to ensure they can care for the health of their inhabitants, for example. With meteorological observations in cities covering stations at different sites and for longer time periods it would be possible to examine the causalities between a changing (warmer) climate and the (spatial distribution of the) occurrence and intensity of the UHI. For the first time, we were able to show that even relatively small urban conglomerates affected by marine weather in mid latitudes, such as Rostock and Stockholm, with 200,000 to 850,000 inhabitants, are subject to a significant UHI effect. Lower UHI intensities can particularly be expected for Rostock, which has only about 200,000 inhabitants and a pronounced land-sea-breeze circulation. This may encourage urban and regional planners to consider specific climatic conditions in urban areas and small-scale climatic influences which can follow from land use changes. For longlasting infrastructure, there may be long-term negative consequences due to the changing climate. However, this may not be the case in the next few years, under certain circumstances. With greater knowledge of the spatial and temporal distribution of the UHI in the case studies, it would be possible to develop specific UHI-mitigation and climate change adaptation measures, which could become important in the future when heat waves are expected to occur more often. This would require a larger observational network or high-resolution model simulations.

\section{Acknowledgements}

The authors would like to thank the Swedish Meteorological and Hydrological Institute (SMHI), the German Meteorological Service (DWD) and the State Office for Environment, Nature Conservation and Geology of Mecklenburg-Vorpommern for providing meteorological data. They are also grateful to the research group plan B: altic for its ongoing discussions and to the German Federal
Ministry of Research and Education for funding the research work from its Social-Ecological Research Programme (FKZ 01UU0909).

\section{REFERENCES}

[1] Intergovernmental Panel on Climate Change, "Climate Change 2007: The Physical Science Basis: Summary for Policy Makers," Paris, 2007.

[2] BACC, "Regional Climate Studies. Assessment of Climate Change for the Baltic Sea Basin," Springer, Berlin, 2008.

[3] H. W. Linderholm, A. Walther and D. Chen, "TwentiethCentury Trends in the Thermal Growing Season in the Greater Baltic Area," Climatic Change, Vol. 87, No. 3-4, 2008, pp. 405-419. doi:10.1007/s10584-007-9327-3

[4] C. Beck, J. Grieser and B. Rudolph, "A New Monthly Precipitation Climatology for the Global Land Areas for the Period 1951 to 2000," Climate Status Report, 2004.

[5] A. Kratzer and Das Stadtklima, "Vieweg," Braunschweig, 1937.

[6] T. R. Oke and F. Hanell, "The Form of the Urban Heat Island in Hamilton, Canada," WMO Technical Note, No. 254, Geneva, 1970.

[7] A. J. Arnfield, "Two Decades of Urban Climate Research: A Review of Turbulence, Exchanges of Energy and Water, and the Urban Heat Island," International Journal of Climatology, Vol. 23, No. 1, 2003, pp. 1-26. doi: $10.1002 /$ joc. 859

[8] T. R. Oke, "City Size and the Urban Heat Island," Atmospheric Environment, Vol. 7, No. 8, 1973, pp. 769-779. doi:10.1016/0004-6981(73)90140-6

[9] I. Camilloni and V. Barros, "On the Urban Heat Island Effect Dependence on Temperature Trends," Climatic Change, Vol. 37, No. 4, 1997, pp. 665-681. doi:10.1023/A:1005341523032

[10] C. J. G. Morris, I. Simmonds and N. Plummer, "Quantification of the Influences of Wind and Cloud on the Nocturnal Urban Heat Island of a Large City," Journal of Applied Meteorology, Vol. 40, No. 2, 2001, pp. 169-182. doi:10.1175/1520-0450(2001)040<0169:QOTIOW $>2.0 . \mathrm{C}$ $\underline{\mathrm{O} ; 2}$

[11] Y. H. Kim and J. J. Baik, "Daily Maximum Urban Heat Island Intensity in Large Cities of Korea," Theoretical and Applied Climatology, Vol. 79, No. 3-4, 2004, pp. 151-164. doi:10.1007/s00704-004-0070-7

[12] K. H. Schlünzen, P. Hoffmann, G. Rosenhagen and W. Riecke, "Long-Term Changes and Regional Differences in Temperature and Precipitation in the Metropolitan Area of Hamburg," International Journal of Climatology, Vol. 30, No. 8, 2010, pp. 1121-1136. doi:10.1002/joc. 1968

[13] B. Crossette, "State of the World Population 2010," United Nations Population Fund, New York, 2010.

[14] B. Früh, P. Becker, T. Deutschländer, J. D. Hessel, M. Kossmann, I. Mieskes, J. Namyslo, M. Roos, U. Sievers, T. Steigerwald, H. Turau and U. Wienert, "Estimation of 
Climate-Change Impacts on the Urban Heat Load Using an Urban Climate Model and Regional Climate Projections," Journal of Applied Meteorology and Climatology, Vol. 50, No. 1, 2011, pp. 167-184. doi:10.1175/2010JAMC2377.1

[15] C. Souch and C. Grimmond, "Applied Climatology: 'Heat waves'," Progress in Physical Geography, Vol. 28, No. 4, 2004, pp. 599-606. doi:10.1191/0309133304pp428pr

[16] Intergovernmental Panel on Climate Change, "Climate Change 2007: The Physical Science Basis. Contribution of Working Group I to the Fourth Assessment Report of the IPCC," Paris, 2007.

[17] L. Filleul, S. Cassadou, S. Médina, P. Fabres, A. Lefranc, D. Eilstein, A. le Tertre, L. Pascal, B. Chardon, M. Blanchard, C. Declercq, J. F. Jusot, H. Prouvost and M. Ledrans, "The Relation between Temperature, Ozone, and Mortality in Nine French Cities during the Heat Wave of 2003," Environmental Health Perspectives, Vol. 114, No. 9, 2006, pp. 1344-1347. doi:10.1289/ehp.8328

[18] M. Rückversicherungsgesellschaft, "Topics: Jahresrückblick Naturkatastrophen," Munich, 2003.

[19] J. A. Patz, D. Campbell-Lendrum, T. Holloway and J. A. Foley, "Impact of Regional Climate Change on Human Health," Nature, Vol. 438, No. 7066, 2005, pp. 310-317. doi:10.1038/nature04188

[20] S. Thorsson, F. Lindberg, J. Björklund, B. Holmer and D. Rayner, "Potential Changes in Outdoor Thermal Comfort Conditions in Gothenburg, Sweden Due to Climate Change: The Influence of Urban Geometry," International Journal of Climatology, Vol. 31, No. 2, 2011, pp. 324-335. doi:10.1002/joc.2231

[21] A. Moberg, H. Alexandersson, H. Bergström and P. D. Jones, "Were Southern Swedish Temperatures before 1860 as Warm as Measured?" International Journal of Climatology, Vol. 23, No. 12, 2003, pp. 1495-1521. doi:10.1002/joc. 945

[22] A. Moberg, H. Bergström, J. Ruiz Krigsmand and O. Svanered, "Daily Air Temperature and Pressure Series for Stockholm (1756-1998)," Climatic Change, Vol. 53, No. 1-3, 2002, pp. 171-212. doi:10.1023/A:1014966724670

[23] A. Moberg and H. Bergström, "Homogenization of Swedish Temperature Data. Part III: The Long Temperature Records from Uppsala and Stockholm," International Journal of Climatology, Vol. 17, No. 1, 1997, pp. 667699.

doi:10.1002/(SICI)1097-0088(19970615)17:7<667::AIDJOC115>3.0.CO;2-J

[24] R. Sneyers, "On the Statistical Analysis of Series of Ob- servations," WMO Technical Note, No. 415, Geneva, 1990.

[25] A. Kulkarni and H. von Storch, "Monte Carlo Experiments on the Effect of Serial Correlation on the MannKendall Test of Trends," Meteorologische Zeitschrift N.F., Vol. 4, No. 2, 1995, pp. 82-85.

[26] P. Štěpánek, "AnClim-Software for Time Series Analysis," 2008.

[27] X. Zhang and F. Yang, "RClimDex (1.0) User Manual," Downsview, 2004.

[28] R. Watkins, J. Palmer, M. Kolokotroni and P. Littlefair, "The Balance of the Annual Heating and Cooling Demand within the London Urban Heat Island," Building Services Engineering Research and Technology, Vol. 23, No. 4, 2002, pp. 207-213. doi:10.1191/0143624402bt043oa

[29] J. P. Montávez, A. Rodríguez and J. I. Jiménez, “A Study of the Urban Heat Island of Granada," International Journal of Climatology, Vol. 20, No. 8, 2000, pp. 899-911. doi:10.1002/1097-0088(20000630)20:8<899::AID-JOC4 33>3.0.CO;2-I

[30] Intergovernmental Panel on Climate Change, "Climate change 2007: Synthesis Report," Paris, 2007.

[31] E. Ripley, O. Archibold and D. Bretell, "Temporal and Spatial Temperature Patterns in Saskatoon," Weather, Vol. 51, No. 12, 1996, pp. 398-403. doi:10.1002/j.1477-8696.1996.tb06171.x

[32] U. Wienert, "Untersuchungen zur Breiten-Und Klimazonenabhängigkeit der Urbanen Wärmeinsel-Eine Statistische Analyse," Essener Ökologische Schriften, No. 16, 2002.

[33] K. Fortuniak, K. Klysik and J. Wibig, "Urban-Rural Contrasts of Meteorological Parameters in Lodz," Theoretical and Applied Climatology, Vol. 84, No. 1-3, 2006, pp. 91101. doi:10.1007/s00704-005-0147-y

[34] U. Wienert and W. Kuttler, "The Dependence of the Urban Heat Island Intensity on Latitude-A Statistical Approach," Metereologische Zeitschrift, Vol. 14, No. 5, 2005, pp. 677-686. doi:10.1127/0941-2948/2005/0069

[35] P. Hoffmann, O. Krueger and K. H. Schlünzen, "A Statistical Model for the Urban Heat Island and Its Application to a Climate Change Scenario," International Journal of Climatology, Vol. 32, No. 8, 2012, pp. 1238-1248. doi: $10.1002 /$ joc 2348

[36] D. J. Jacob and D. A. Winner, "Effect of Climate Change on Air Quality," Atmospheric Environment, Vol. 43, No. 1, 2009, pp. 51-63. doi:10.1016/j.atmosenv.2008.09.051 